citizens, ten patients, two marketeers and two experts in mobile health applications participated. A participatory design methodology was followed in order to capture \& address the whole user experience.

Results: An iterative process was followed bringing \& different end-users on board. The different parties evaluated and assessed all modules implemented providing appropriate feedback. It currently runs only on Android operating system and supports: (i) pain management (intense \&points of pain, medications used, underlying diseases, life style, etc.),(ii) raise awareness \& education (through information nuggets \& bite-sized learning), (iii) "Share your story" option to inspire others, (iv) fund raising using crowd-funding techniques, (v) become a volunteer, (vi) organize an inspiring event, (vii) networking, (viii) automatic creation of infographics on how pain affects peoples' lives. It has been awarded the first prize by BMP Innovation Grant.

Conclusion: StigmApp has been designed to support the ecosystem around chronic pain regardless of the underlying disease. Our main concern is to raise awareness in order to fight stigma associated with pain \& make life easier for patients \& their families. The involvement of all different potential actors in the design guarantees a product/service that could meet their needs \& can be applied in real life. In the next months the final solution will be piloted by a number of different end users in order to assess it under real life conditions.

REFERENCES:

[1] Fayaz A, Croft P, Langford RM, Donaldson LJ, Jones GT. Prevalence of chronic pain in the UK: a systematic review \& meta-analysis of population studies. BMJ Open 2016 Jun 20;6(6):e010364. DOI:10.1136/bmjopen-2015-010364. PMID:27324708; PMCID: PMC4932255.

[2] Koumpouros $Y$, Georgoulas A. A systematic review of mhealth funded R\&D activities in EU. Trends, technologies and obstacles, Informatics for Health\&Social Care. 2020;45(2):168-187. DOI:10.1080/17538157.2019.1656 208. Epub2019 Nov 19. PMID:31743060.

[3] Lalloo C, Jibb LA, Rivera J, Agarwal A, Stinson JN. There's a Pain App for That: review of patient-targeted smartphone applications for pain management.Clin J Pain.2015;31(6):557-63. DOI:10.1097/AJP.0000000000000171.

[4] De Ruddere, Liesa, Craig, Kenneth D. Understanding stigma \& chronic pain:a-state-of-the-art review,PAIN:August 2016-Volume 157-Issue 8-p16071610, doi:10.1097/j.pain.0000000000000512

Acknowledgements: The project is funded by the Brain, Mind, and Pain, Patient-Centred Innovation Grant.

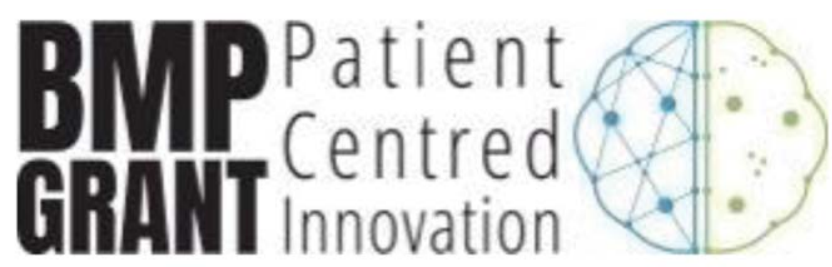

Many thanks to the two patient organizations Hellenic League Against Rheumatism \& Cyprus League Against Rheumatism for their valuable contribution in the project.

Disclosure of Interests: None declared.

DOI: 10.1136/annrheumdis-2021-eular.2398

\section{POS0065-PARE HEALTH IMPACT OF OVERWEIGHT AND OBESITY IN PATIENTS WITH AXIAL SPONDYLOARTHRITIS RESULTS FROM THE EUROPEAN MAP OF AXIAL SPONDYLOARTHRITIS (EMAS)}

M. Garrido-Cumbrera ${ }^{1}$, D. Poddubnyy ${ }^{2}$, L. Christen ${ }^{3}$, C. Bundy ${ }^{4}$, R. Mahapatra ${ }^{5}$, S. Makri' ${ }^{6}$, S. Sanz-Gómez ${ }^{1}$, J. Correa-Fernández ${ }^{1}$, C. J. Delgado-Domínguez', V. Navarro-Compán ${ }^{7}$ on behalf of IMAS working group. ${ }^{1}$ Universidad de Sevilla, Health \& Territory Research (HTR), Seville, Spain; ${ }^{2}$ Charité - Universitätsmedizin Berlin, Rheumatology Department, Berlin, Germany; ${ }^{3}$ Novartis Pharma AG, Patient Engagement, Basel, Switzerland; ${ }^{4}$ Cardiff University, School of Healthcare Sciences, Cardiff, United Kingdom; ${ }^{5}$ Axial Spondyloarthritis International Federation (ASIF), Patient Advocacy, London, United Kingdom; ${ }^{6}$ Cyprus League Against Rheumatism (CYPLAR), Patient Advocacy, Nicosia, Cyprus; ${ }^{7}$ Hospital Universitario La Paz, IdiPaz, Madrid, Spain

Background: Growing evidence on the negative role of overweight and obesity on the health outcomes of patients with axial spondyloarthritis (axSpA) exists. Objectives: The aim of the study is to evaluate the association between Body Mass Index (BMI) categories and sociodemographic, disease-characteristics and patient-reported outcomes (PROs) in a large sample of axSpA patients. Methods: Data from 2,846 unselected patients of the European Map of Axial Spondyloarthritis (EMAS) through an online survey (2017-2018) across 13 European countries were analyzed. Using self-reported height and weight patients were classified into under and normal weight $\left(<24.9 \mathrm{Kg} / \mathrm{m}^{2}\right)$, overweight $\left(25.0-29.9 \mathrm{Kg} / \mathrm{m}^{2}\right)$ or obese $\left(>30.0 \mathrm{Kg} / \mathrm{m}^{2}\right)$ following WHO guidelines. The Kruskal-Wallis test was used to compare the means of numerical variables between polytomous variables, the $\chi^{2}$ test was used to compare the distribution between the categorical variables. Simple and multivariate logistic regression were used to identify possible associated factors.

Results: A total 2,846 axSpA patients participated in the EMAS survey: mean age was 43.9 years, $61.3 \%$ female, $48.1 \%$ had a university degree and $67.9 \%$ were married and $71.3 \%$ were HLA-B27 positive. The percentage of patients with obesity was $18.7 \%$, overweight $33.5 \%$, normal weight $44.0 \%$ and underweight $3.8 \%$ with an accumulate prevalence of overweight/obesity of $52.2 \%$ (compared to $51.6 \%$ of the EU's population $\left.{ }^{1}\right)$. Those with obesity engage less frequently in sport $(50.1 \%$ vs $33.3 \%$; $p<0.001)$ and in intimate relationships since disease onset $(36.5 \%$ vs $20.4 \%$; $\mathrm{p}<0.001)$, have higher functional limitations when tying shoe laces $(46.8 \%$ vs $33.6 \%$; $p<0.001)$ and higher functional limitations regarding housework $(52.2 \%$ vs $48.2 \%$; $\mathrm{p}=0.024)$. Furthermore, they present greater disease activity $(6.1 \pm 1.8$ vs $5.4 \pm 2.0$ $\mathrm{p}<0.001)$ and spinal stiffness $(8.6 \pm 2.3$ vs $7.4 \pm 2.5 ; p<0.001)$ compared to under and normal weight. For obese patients, the percentage of depression is higher (34.5\% vs $23.7 \% ; p<0.001)$, presenting a poorer mental health $(5.7 \pm 4.3$ vs $5.0 \pm 4.2 ; p<0.001)$ The factors most strongly associated with obesity were higher functional limitation when tying shoe laces $(O R=1.467 ; p<0.001)$, the female gender $(O R=1.433$ $p<0.001)$ and lesser frequency of intimate relation ( $O R=1.239 ; p<0.001$; see Table 1).

Table 1. Logistic regression analysis to predict presence of obesity $(\mathrm{N}=$ 1,194)

\begin{tabular}{|c|c|c|c|c|c|c|}
\hline & \multicolumn{3}{|c|}{ Simple } & \multicolumn{3}{|c|}{ Multivariate } \\
\hline & OR & $95 \% \mathrm{Cl}$ & p-value & OR & $95 \% \mathrm{Cl}$ & p-value \\
\hline Age & 1.026 & $1.018,1.034$ & $<0.001$ & 1.026 & $1.012,1.040$ & $<0.001$ \\
\hline Gender (female) & 1.336 & $1.095,1.629$ & 0.004 & 1.433 & $1.031,1.990$ & 0.032 \\
\hline Marital status (married) & 1.384 & $1.184,1.617$ & $<0.001$ & 0.982 & $0.746,1.292$ & 0.897 \\
\hline $\begin{array}{l}\text { Educational level } \\
\text { (university) }\end{array}$ & 0.776 & $0.681,0.884$ & $<0.001$ & 1.046 & $0.849,1.289$ & 0.674 \\
\hline $\begin{array}{l}\text { Employment status } \\
\text { (employed) }\end{array}$ & 1.035 & $0.987,1.085$ & 0.154 & NA & NA & NA \\
\hline $\begin{array}{l}\text { Engage in sports (much } \\
\text { less than before) }\end{array}$ & 1.313 & $1.202,1.433$ & $<0.001$ & 1.143 & $0.978,1.336$ & 0.093 \\
\hline $\begin{array}{l}\text { Travel/ excursions } \\
\text { (much less than } \\
\text { before) }\end{array}$ & 1.316 & $1.186,1.461$ & $<0.001$ & 0.981 & $0.800,1.202$ & 0.852 \\
\hline $\begin{array}{l}\text { Intimate relations (much } \\
\text { less than before) }\end{array}$ & 1.571 & $1.393,1.772$ & $<0.001$ & 1.239 & $1.003,1.530$ & 0.047 \\
\hline Tying shoe laces (high) & 1.433 & $1.232,1.666$ & $<0.001$ & 1.467 & $1.176,1.830$ & 0.001 \\
\hline $\begin{array}{l}\text { Housework / cleaning } \\
\text { (high) }\end{array}$ & 1.226 & $1.048,1.434$ & 0.011 & 0.760 & $0.596,0.970$ & 0.028 \\
\hline BASDAI $(0-10) \mathrm{N}: 2,584$ & 1.220 & $1.156,1.288$ & $<0.001$ & 1.127 & $1.021,1.244$ & 0.018 \\
\hline $\begin{array}{l}\text { Spinal Stiffness (3-12) } \\
\quad \mathrm{N}: 2,660\end{array}$ & 1.184 & $1.136,1.234$ & $<0.001$ & 1.057 & $0.987,1.133$ & 0.115 \\
\hline $\begin{array}{l}\text { Sleep disorders } \\
\text { diagnosis }\end{array}$ & 1.558 & $1.284,1.892$ & $<0.001$ & 1.045 & $0.753,1.449$ & 0.793 \\
\hline Depression diagnosis & 1.648 & $1.340,2.027$ & $<0.001$ & 1.267 & $0.892,1.799$ & 0.186 \\
\hline $\begin{array}{l}\text { Psychological distress } \\
\text { GHQ-12 (0-12) }\end{array}$ & 1.053 & $1.029,1.078$ & $<0.001$ & 0.995 & $0.954,1.038$ & 0.813 \\
\hline
\end{tabular}

Conclusion: Results from the largest European axSpA survey reveal a simila prevalence of overweight and obesity to the general population. However, compared to normal weight, obese patients present greater disease activity, spinal stiffness and poorer mental health. Additionally, women with axSpA appear to be more vulnerable than men to obesity.

REFERENCES:

[1] EU Eurostat. Overweight and obesity - BMI statistics.

Acknowledgements: This study was supported by Novartis Pharma AG. The authors would like to thank all patients who participated in the study.

Disclosure of Interests: Marco Garrido-Cumbrera: None declared, Denis Poddubnyy Speakers bureau: Abbvie, BMS, Celgene, Janssen, Lilly, MSD, Novartis, Pfizer, Roche, and UCB, Grant/research support from: Abbvie, MSD, Novartis and Pfizer, Laura Christen Employee of: Novartis Pharma AG, Christine Bundy Speakers bureau: Abbvie, Celgene, Janssen, Lilly, Novartis, and Pfizer, Ra Mahapatra: None declared, Souzi Makri: None declared, Sergio Sanz-Gómez: None declared, José Correa-Fernández: None declared, Carlos Jesús Delgado-Domínguez: None declared, Victoria Navarro-Compán Grant/research support from: Abbvie, BMS, Lilly, MSD, Novartis, Pfizer, Roche, and UCB. DOI: 10.1136/annrheumdis-2021-eular.974

\section{POS0066-PARE REHABILITATION WITH KINESIOTHERAPY IN MUSCLE FUNCTION AND WEIGHT LOSS IMPROVING IN OBESITY PATIENTS}

V. Vasileva ${ }^{1}$, M. Eryomushkin ${ }^{1}$, L. Marchenkova ${ }^{1} .{ }^{1}$ National Medical Research Center of Rehabilitation and Balneology, National Medical Research Center of Rehabilitation and Balneology, Moscow, Russian Federation 
Background: exercise is one of the main factors for the successful treatment of obesity. It is known that with increasing age, muscle strength (sarcopenic obesity) decreases in an obese patient, which can lead to early disability and an increased risk of falls. Regular exercise therapy increases the functional capacity of the cardiovascular system, prevention of obesity among the population, as well as treatment for persons with sarcopenia and obesity. Therefore, it is relevant to study muscle function in obese patients while using kinesiotherapy.

Objectives: was to estimate the affect of complex 3-week treatment with 4 kinesiotherapy methods on body weight loss and muscle function in patients with obesity.

Methods: 80 men and women aged 21-69 years old with alimentary obesity were enrolled in the study (mean age $52.4 \pm 11$ years, weight $111.3 \pm 24.5 \mathrm{~kg}$, BMI $40.3 \pm 8.1 \mathrm{~kg} / \mathrm{m} 2$, waist circumstance WC $113.4 \pm 16 \mathrm{~cm}$, hip circumstance HC $124.2 \pm 16 \mathrm{~cm})$. The complex kinesiotherapy administered daily for 3 week and included interactive sensorimotor trainings on double unstable platform, kinesiohydrotherapy in a pool, special complex of physical exercises in a gym and ergocycle trainings. Weight, $\mathrm{WC}, \mathrm{HC}$, fall number for last 3 weeks were measured at baseline and after the treatment was completed. Muscle strength and walking speed functional tests results assessment (10-meters-walk test, Up-and-go test, 4 special tests for back and abdomen muscle endurance to static and dynamic loading) were performed at baseline and in 3 weeks.

Results: there was a significant reduction in body weight $(111.3 \pm 24.4 \mathrm{~kg}$ at baseline vs $107.9 \pm 23.1 \mathrm{~kg}$ in 3 weeks; $p=0,000)$, in BMl $(40.3 \pm 8.1 \mathrm{vs} 39.1 \pm 7.7 \mathrm{~kg} /$ $\left.\mathrm{m}^{2} ; \mathrm{p}=0.000\right)$, in WC $(113.4 \pm 15.9$ vs $109.2 \pm 15.1 \mathrm{~cm} ; \mathrm{p}=0.000)$ and in $\mathrm{HC}$ $(124.1 \pm 15.5$ vs $119.7 \pm 14.1 \mathrm{~cm} ; \mathrm{p}=0.000)$ in treated obese patients. 10-meterswalk speed increased from $0.84 \pm 0.15 \mathrm{~m} / \mathrm{sec}$ at baseline to $0.88 \pm 0.17 \mathrm{~m} / \mathrm{sec}$ in 3 weeks $(p=0.000)$. Up-and-go test results improved from $8.4 \pm 2.1$ to $7.9 \pm 2.09 \mathrm{sec}$ $(p=0.000)$. We registered statistically significant elevation of the endurance to static loading in abdomen muscles from $13.1 \pm 9.7$ to $16.49 \pm 12.8 \mathrm{sec}(p=0.000)$ and in back muscles from $14.8 \pm 11.9 \mathrm{sec}$ to $18.6 \pm 14.9 \mathrm{sec}(p=0.000)$. The endurance to dynamic loading increased in abdomen muscles from $29.9 \pm 11.2$ to $34.84 \pm 11.93$ times $(p=0.000)$ and also in back muscles from $9.1 \pm 7.4$ to $12.2 \pm 9.2$ times $(\mathrm{p}=0.000)$. Fall namber markably decreased from $0.14 \pm 0.34$ at baseline to 0.0 (95\% Cl: $0.02 ; 0.25)$ after completion of treatment

Conclusion: investigated complex treatment with 4 kinesiotherapy methods promotes body weight loss, WC and $\mathrm{HC}$ reduction in obesity. 3-week special training of obese patients is associated with increasing in gate speed and lower extremities muscle strength, and it also causes improvement in static and dynamic loading endurance of back and abdomen muscles. Those changes may probably improve balance function and decrease risk of falling in obese patients. REFERENCES:

[1] O.Lee, DS. Lee, S.Lee, Associations between Physical Activity and Obesity Defined by waist - to-height ratio and body mass index in the Korean Population. // PLOS ONE- 11(7). -2016. P. 1-11.

[2] I.I. Baidovletova, Physiotherapy for obesity. // Psychology and pedagogy: methods and problems. 2015.- S. 177-180.

[3] L. A. Marchenkova, V. A. Vasileva, Motor and balance function disorders and possibilities of their correction in patients with obesity and metabolic syndrome // Lechashchiy vrach. 2019. № 4. S. 68.

Disclosure of Interests: None declared.

DOI: 10.1136/annrheumdis-2021-eular.3065

\section{Pediatric Rheumatology - Basic and translational science}

\section{POS0067 HIGH DEGREE OF INTER-PATIENT HETEROGENEITY IN SYNOVIOCYTE HYPERPLASIA AND IMMUNE CELLS INFILTRATION IN THE SYNOVIUM OF JUVENILE IDIOPATHIC ARTHRITIS PATIENTS}

C. Triaille $^{1,2}$, C. Boulanger ${ }^{2,3}$, T. Sokolova ${ }^{1}$, L. Meric de Bellefon ${ }^{1,4}$, A. Nzeusseu Toukap $^{1,4}$, C. Galant ${ }^{5}$, N. Limaye ${ }^{3}$, B. Lauwerys ${ }^{1,4}$, P. Durez ${ }^{1,4}$. ${ }^{1}$ Université catholique de Louvain, Pôle de pathologies rhumatismales systémiques et inflammatoires, Institut de Recherche Expérimentale et Clinique, Brussels, Belgium; ${ }^{2}$ Cliniques Universitaires Saint-Luc, Service d'Hématologie, Oncologie et Rhumatologie pédiatrique, Brussels, Belgium; ${ }^{3}$ Université catholique de Louvain, Genetics of Autoimmune Diseases and Cancer, de Duve Institute, Brussels, Belgium; ${ }^{4}$ Cliniques Universitaires Saint-Luc, Service de Rhumatologie, Brussels, Belgium; ${ }^{5}$ Cliniques Universitaires Saint-Luc, Service d'Anatomie Pathologique, Brussels, Belgium

Background: Increasing evidence indicates that synovial tissue analysis can deliver pathophysiological insights but also individual clinically-relevant information in adult-onset inflammatory arthritides. Little is known about synovial pathology in juvenile idiopathic arthritis, especially regarding inter-patient variability of histopathological features.
Objectives: To assess the heterogeneity of main synovial features (synoviocyte hyperplasia and immune cells infiltration) in juvenile idiopathic arthritis (JIA) patients and a cohort of young adults ( $<30$ years old) with early rheumatoid arthritis (RA)

Methods: Synovial biopsies were sampled using needle arthroscopy or ultrasound (US) guided biopsy during intra-articular joint injection. Tissue was embedded in paraffin then sections were stained with hematoxylin and eosin. Synoviocyte hyperplasia (SH) and immune cells infiltration $(\mathrm{ICl})$ was assessed by an experienced pathologist on a $0-3$ scale where 0 represents the absence of the feature and 3 the highest level.

Results: 34 JIA patients (age (median \pm SD): $15.5 \pm 6.47$ years, oligo-articular JIA $n=28 / 34$, polyarticular JIA $n=6 / 34$, ANA-RF-ACPA positivity $=56 \%-10 \%-3 \%$ ) and 22 RA (age (median $\pm S D$ ): $24.3 \pm 2.6$ years, ANA-RF-ACPA positivity $=10 \%-36 \%-32 \%$ ) patients were included. Synovial tissue was obtained from knee $(n=49 / 56)$, wrist $(n=4 / 56)$ or metacarpophalangeal/intercarpophalangeal joints $(n=3 / 56)$, using US guided biopsy in $27 \%$ of patients and needle arthroscopy in $73 \%$.

Individual scores of SH and ICI were correlated in both JIA (Spearman's $r=0.503$ $\mathrm{p}$ value $=0.0024$ ) and RA (Spearman's $r=0.636$, $\mathrm{p}$ value $=0.0015)$. There was no significant difference in $\mathrm{SH}$ and $\mathrm{ICl}$ scores between the 2 groups (SH score (Q25-Q50-Q75) in $\mathrm{JIA}=0.5-1.125-2$ and in $R A=0.75-2-2 ; \mathrm{ICl}$ score $(\mathrm{Q} 25$ $\mathrm{Q} 50-\mathrm{Q} 75)$ in $\mathrm{JIA}=1-2-2$ and in $\mathrm{RA}=0.75-2-2.25)$. Intra-group variability of the two assessed features was comparable between the 2 groups ( $\mathrm{SH}$ coefficient of variation: $72.2 \%$ for $\mathrm{JIA}$ and $68.2 \%$ for $\mathrm{RA}$; ICI coefficient of variation: $52.2 \%$ for JIA and $71.2 \%$ for RA). Within JIA patients, there was no significant difference in $\mathrm{SH} / \mathrm{ICl}$ scores between groups based on ANA positivity, oligo or polyarticular involvement nor ongoing treatment.

Conclusion: Studying main histological features of synovitis, we found no difference between JIA and young RA patients. Furthermore, we report a simila degree of inter-patient heterogeneity in synovial pathological features of JIA and RA patients. These variations were not explained by common clinical character istics. Whether they relate to different molecular signatures as suggested in adult RA will be further investigated using bulk tissue RNA sequencing.

Acknowledgements: This work was funded in part by Cap48 (RTBF). Clément Triaille is funded by the Fonds National de la Recherche Scientifique (FNRS Communauté française de Belgique) and Fondation Saint-Luc (Cliniques Universitaires Saint-Luc).

Disclosure of Interests: Clément Triaille: None declared, Cécile Boulanger: None declared, Tatiana Sokolova: None declared, Laurent Meric de Bellefon: None declared, Adrien Nzeusseu Toukap: None declared, Christine Galant: None declared, Nisha Limaye: None declared, Bernard Lauwerys Employee of: currently employed at UCB Biopharma, Patrick Durez: None declared. DOI: 10.1136/annrheumdis-2021-eular.2100

\section{POS0068 HIGH LEVELS OF PORPHYROMONAS GINGIVALIS AND PREVOTELLA INTERMEDIA ANTIBODIES IN CHILDREN WITH JUVENILE IDIOPATHIC ARTHRITIS}

F. Zekre ${ }^{1}$, R. Cimaz ${ }^{2}$, M. Paul ${ }^{3}$, J. L. Stephan ${ }^{4}$, S. Paul ${ }^{5}$, H. Marotte ${ }^{6} .{ }^{1}$ INSERM U1111-CNRS. INSERM U1059-SAINBIOSE, Campus Santé Innovations Faculté de Médecine Jacques Lisfranc, Saint Priest en Jarez, France; ${ }^{2}$ Università degli studi di Milano Statale, Reumatologia pediatrica, Milano, Italy; ${ }^{3}$ INSERM U1059, SAINBIOSE, Université de Lyon, Saint Etienne, Saint Priest en Jarez, France; ${ }^{4}$ Hôpital Nord, Service pédiatrie, CHU Saint Etienne, Saint Priest en Jarez, France; ${ }^{5}$ INSERM U1111-CNRS, Université de Lyon, Saint-Etienne, Saint Priest en Jarez, France; ${ }^{6}$ INSERM U1059, SAINBIOSE, Université de Lyon, SaintEtienne, France, Saint Priest en Jarez, France

Background: Idiopathic juvenile arthritis (JIA) is a heterogeneous group of pathologies whose origin remains unknown at present (1). They are characterised by a systemic inflammatory and joint disease affecting children under 16 years of age. The current classification groups the different forms of JIA into 7 distinct entities (systemic forms, polyarticular forms with or without rheumatoid factors, oligoarticular forms, inflammatory arthritis associated with enthesopathies (ERA), arthritis associated with psoriasis and unclassifiable arthritis). Exact etiology of JIA is still unknown. To date, the various hypotheses put forward on the occurrence of JIAs integrate the genetic and environmental framework. The link between periodontal disease and rheumatoid arthritis (RA) is largely reported. Recently, Porphyromonas gingivalis ( $P$. gingivalis) infection explained the occurrence of arthritis in rodent and in RA (2). Several studies mention the beneficial effect of $P$. gingivalis treatment on disease activity.

Currently, there are very few studies on the prevalence of $P$. gingivalis in patients with JIA and the possible involvement of the germ in the development of inflammatory joint diseases in the pediatric population(3)(4).

Objectives: The objective of our study is to determine presence of high IgG antibodies against $P$. gingivalis and Prevotella Intermedia in a cohort of patients with JIA compared to a control population and to determine variation of level according to sub-classes of JIA. 